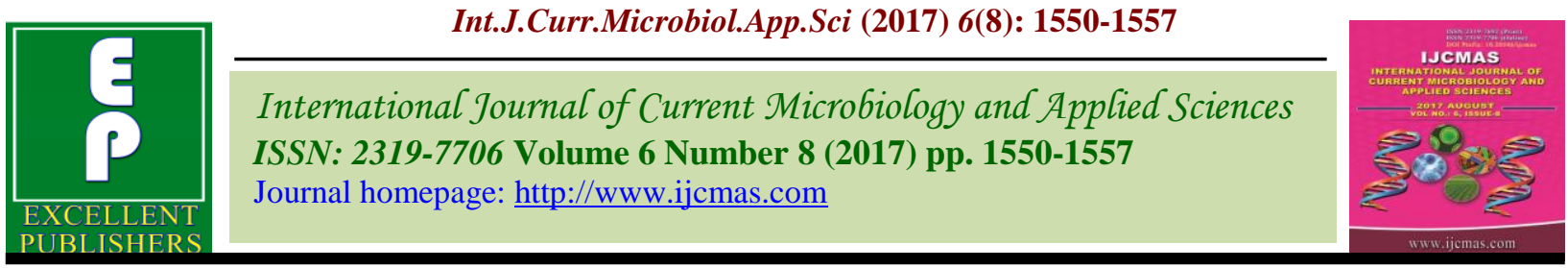

Original Research Article

https://doi.org/10.20546/ijcmas.2017.608.186

\title{
Genetic variability and Path Analysis in Opium Poppy (Papaver somniferum L.)
}

\author{
Santra Haritwal*, N.S. Dodiya and C.L. Khatik \\ Department of Plant Breeding and Genetics, Rajasthan College of Agriculture, \\ MPUAT, Udaipur, Rajasthan-313001, India \\ *Corresponding author
}

\section{A B S T R A C T}

A field experiment was conducted during rabi season of 2016-17 at Research Farm, Rajasthan College of Agriculture, MPUAT, Udaipur to study " Genetic Variability and Path Analysis in Opium poppy (Papaver somniferum L.)" was carried out using 25 genotypes were planted in randomized block design including 2 checks. The data obtained were subjected to analysis of variance, estimation of different variability parameters and

Keywords

Genetic

variability, Path analysis, Opium poppy, Seed yield, Latex yield.

Article Info

Accepted:

17 June 2017

Available Online:

10 August 2017 path coefficient analysis. The observations were recorded on five randomly selected plants for twelve characters. Analysis of variance revealed significant differences among the genotypes for all the characters suggesting sufficient amount of variability in the experimental material under study. High GCV coupled with high heritability and expected genetic gain of a character provides good selection advantage. There is a substantial scope for improvement of seed yield per plant, harvest index for latex yield and husk yield per plant. Selection for these characters would be effective in selection of suitable genotype for opium poppy improvement. Path coefficient analysis revealed that husk yield per plant, number of effective capsule per plant, diameter of main capsule, days to 50 per cent flowering, plant height and was the major components for seed yield per plant and latex yield per plant respectively because these traits had maximum direct and indirect effect towards seed yield and latex yield. The estimate of phenotypic coefficient of variance was higher in magnitude than the respective genotypic coefficient of variance for all the characters indicating the important role of environment in the expression of characters. Chetek Aphim (0.16 g), UOP 121 (0.15g/plant), UOP 30 (0.14g/plant) and UOP $53(0.13 \mathrm{~g} /$ plant $)$ were found superior for latex yield and genotype UOP 53 (7.52 g/plant), UOP 150 (6.41 g/plant) and JOP 540 (6.31g/plant) for seed yield. The genotype UOP-53 found superior for both latex and seed yield per plant.

\section{Introduction}

Opium poppy (Papaver somniferum L.) is a multipurpose crop which is used as a medicinal or ornamental plant, as well as a source for seeds and seed oil.

It is chief source of diverse physiologically active alkaloids and known to mankind since antiquity. Opium is one of the oldest known pain killers and is source of several alkaloids used for analgesic, hypnotic, sedative, antispasmodic and soporific purpose in modern medicine.

Morphine is the major alkaloid present in opium ranges from 7-17 per cent mainly used to relieve from almost all type of severe pains. 
Other important alkaloids are codeine, the baine papaverine and narcotine. Papaver somniferum $\mathrm{L}$. is an annual plant $(2 \mathrm{n}=22)$ native to Turkey and adjacent areas Opium poppy is considered to be a predominantly self-pollinating species with various rates of out-crossing depending upon variety and environmental factors where the degree of out crossing is reported from 70-72 per cent. It is traditionally grown as Rabi, crop. Opium poppy is an erect annual plant that usually has a white, purple, or pink terminal flower, and alternating leaves. The petals surround the unripe fruit capsule until the fruit capsule matures then the petals fall off. The characteristic fruit type of opium is the unilocular capsule. The stigmatic disc rests on top of the capsule, and beneath it are dehiscent pores or valves. The flowers have two sepals that fall off as the bud opens and four (or up to six) petals in red, pink, orange and white.

Poppy seeds are devoid of narcotic properties and are rich in fatty oils and proteins. Poppy seeds contain up to 50 percent edible oil and cultivar having high levels of oleic and linoleic acids. The oil is widely used for culinary purposes. They are also the source of drying oil, used for manufacturing of paints, varnishes and soaps. The crop is mainly grown in India, China, and Egypt and in India. It is cultivated in the states of Madhya Pradesh, Rajasthan and Uttar Pradesh under the control of Narcotics Department by licensed growers and is a valuable source of foreign exchange. In India, it is cultivated on an area of 5328 ha with a production and productivity of 317.86 tones at 70 consistency and $59.65 \mathrm{Kg} / \mathrm{ha}$ and in Rajasthan, it is cultivated on an area of 2503 ha with a production and productivity of 158.4 tones at 70 consistency and $63.28 \mathrm{Kg} / \mathrm{ha}$ during 2013 14, respectively (Khatik et al., 2016). The extant of possible improvement for a particular character mainly depends upon the genetic variability and its heritable proportion like seed yield, latex yield, a polygenic trait where direct selection would not be reliable approach on account of being highly influenced by environmental factors. Hence it becomes very essential to identify the direct as well as indirect component traits which can be biometrically estimated by path coefficients.

\section{Materials and Methods}

The present research entitled "Genetic Variability and Path Analysis in opium poppy (Papaver somniferum L.)" was carried out with 25 diverse genotypes in randomized block design replicated thrice at Research Farm, Rajasthan College of Agriculture, MPUAT, Udaipur, during Rabi 2016-17. Each entry was planted in 2 rows of $3.0 \mathrm{~m}$ length keeping row to row and plant to plant distance of $30 \mathrm{~cm}$ and $10 \mathrm{~cm}$, respectively. The observations were recorded on five randomly selected competitive plants for each entry in replication for all the morphological characters. However, the observations days to 50 per cent flowering and maturity were recorded on plot basis. And other observation of each entry in each replication was recorded for peduncle length, plant height, number of effective capsule per plant, diameter of main capsule, number of leaves per plant, seed yield per plant, husk yield per plant, latex yield per plant, harvest index for seed yield, harvest index for latex yield.

\section{Results and Discussion}

The genetic variability present in the population is a prerequisite for progress of any breeding programme. The estimates of various variability parameters viz., GCV, PCV, heritability and genetic gain are given in (Table 1). The highest phenotypic coefficient of variation was observed for number of effective capsule per plant 
(28.39\%) followed by seed yield per plant $(21.15 \%)$. The highest genotypic coefficient of variation was observed for husk yield per plant $(19.56 \%)$ followed by seed yield per plant (18.58\%), latex yield per plant (14.23), harvest index for latex yield (13.84\%) and number of effective capsule per plant $(13.52 \%)$. The estimate of phenotypic coefficient of variance was higher in magnitude than the respective genotypic coefficient of variance for all the characters indicating the important role of environment in the expression of characters. The differences between genotypic coefficient of variance and phenotypic coefficient of variance estimates were negligible for plant height while the difference was high for rest of the characters. Similar findings on variability on genotypic and phenotypic level in opium poppy have also reported by Jain et al., (2005), and Singh et al., (2008).

Heritability (in broad sense) is the ratio of genotypic variance to the phenotypic variance. It determines the efficiency with which we can utilize the genotypic variability in breeding programme. The results indicated that the heritability was high for most of the characters. Husk yield per plant showed maximum heritability $(89.53 \%)$ followed by seed yield per plant $(77.18 \%)$, harvest index for latex yield $(68.75 \%)$, diameter of main capsule $(64.16 \%)$, index for seed yield (58.38\%), Latex yield per plant (56.21\%),plant height $(48.79 \%)$, number of leaves per plant $(37.64 \%)$. Similar results were also reported for high heritability for the characters viz., plant height, diameter of main capsule, days of $50 \%$ flowering, number of leaves per plant, husk yield per plant and seed yield per plant by Jain et al., (2005), Singh et al., (2008).

Genetic advance (GA) expressed as percentage of mean was maximum for harvest index for seed yield (5.52\%) followed by plant height $(5.29 \%)$ and diameter of main capsule $(3.91 \%)$. Higher magnitude of genetic advance was also observed for plant height by Singh et al., (2000). Genetic advance as per cent of mean is expressed as genetic gain. The highest genetic gain was observed for husk yield per plant $(38 \%)$ followed by seed yield per plant $(33.63 \%)$, latex yield per plant $(22.13 \%)$ and harvest index for latex yield $(20.07 \%)$. In consonance to present findings, Jain et al., (2005) also observed higher estimates of genetic gain for seed yield per plant $(38 \%)$ in opium poppy. Selection for these characters would be effective in selection of suitable genotype for Opium poppy improvement. Genetic advance as per cent of mean is expressed as genetic gain. The highest genetic gain was observed for husk yield per plant $(38 \%)$ followed by seed yield per plant $(33.63 \%)$, latex yield per plant $(22.13 \%)$ and harvest index for latex yield $(20.07 \%)$. The magnitude of genetic gain was medium for number of effective capsule per plant (13.26\%), number of leaves per plant (11.78 \%), harvest index for seed yield $(11.12 \%)$, diameter of main capsule $(9.35 \%)$ and plant height $(5.30 \%)$. Low estimates of genetic gain were recorded for peduncle length $(3.91 \%)$ and days to 50 per cent flowering $(2.64 \%)$. Very low estimates of genetic gain were recorded for days to maturity $(1.28 \%)$. In consonance to present findings, Jain et al., (2005) also observed higher estimates of genetic gain for husk yield per plant $(38 \%)$ in opium poppy

Path analysis provides information about how close the other traits to the yield. The direct and indirect effects of five dependent characters on seed yield per plant and latex yield per plant as independent character was obtained in path coefficient analysis at genotypic level. The results and discussed for path analysis as under. Husk yield v/s seed yield per plant: A perusal of the (Table 2) indicated that the significant positive 
correlation of husk yield per plant with seed yield per plant $(0.773 * *)$ was mainly due to its high positive indirect effect via latex yield per plant (0.041), peduncle length (0.002) and days to maturity (0.001) whereas husk yield per plant exerted maximum direct effect seed yield per plant with high negative estimated number of leaves per plant $(-0.014)$, days to $50 \%$ flowering $(-0.010)$ and diameter of main capsule.

Latex yield per plant v/s seed yield per plant: A perusal of the (Table 2) indicated that the significant positive correlation of latex yield per plant with seed yield per plant $(0.574 * *)$ was mainly due to its high positive indirect effect via Diameter of main capsule (0.0533) and number of effective capsule per plant (0.037) whereas peduncle length (-0.01) and plant height $(-0.006)$ exerted maximum direct effect on seed yield per plant with high negative estimates. Diameter of main capsule v/s seed yield per plant: A perusal of the (Table 2) indicated that the significant positive correlation of diameter of main capsule with seed yield per plant $(0.563 * *)$ was mainly due to its high positive indirect effect via husk yield per plant (0.287), latex yield per plant (0.053), number of effective capsule per plant (0.011) and days to maturity (0.007).whereas peduncle length $(-0.02)$, day and plant height (-0.01) exerted maximum direct effect on seed yield per plant is negative.

Number of effective capsule per plant v/s seed yield per plant: A perusal of the (Table 2) indicated that the significant positive correlation of number of effective capsule per plant with seed yield per plant $(0.294 * *)$ was mainly due to its high positive indirect effect via husk yield per plant (0.425), latex yield per plant (0.037), peduncle length (0.041) and plant height(0.003) whereas diameter of main capsule (-0.012), number of effective capsule per plant $(-0.035)$ and days to $50 \%$ flowering $(-0.02)$ exerted maximum direct effect on seed yield per plant with high negative estimates.

Peduncle length v/s seed yield per plant: A perusal of the (Table 2) indicated that the significant positive correlation of peduncle length with seed yield per plant $\left(0.381^{* *}\right)$ was mainly due to its high positive indirect effect via husk yield per plant (0.014), peduncle length (0.110) and plant height(0.004) whereas number of effective capsule per plant $(-0.013)$, latex yield per plant $(-0.01)$ and diameter of main capsule (-0.006) exerted maximum direct effect on seed yield per plant with high negative estimates.

Table.1 Estimates of genotypic coefficient of variation (GCV), phenotypic coefficient of variation $(\mathrm{PCV})$, heritability in broad sense $\left(\mathrm{h}^{2}\right)$, genetic advance $(\mathrm{GA})$ and Genetic gain $(\mathrm{GG})$ for different characters in Opium poppy

\begin{tabular}{llllll}
\hline Characters & GCV & PCV & $\mathbf{h}^{2}$ & GA & GG \\
\hline Days to 50\% flowering & 2.18 & 3.71 & 34.57 & 2.20 & 2.64 \\
Peduncle length (cm) & 3.98 & 8.32 & 22.87 & 0.93 & 3.91 \\
Plant height (cm) & 3.69 & 5.28 & 48.79 & 5.29 & 5.30 \\
Number of leaves per plant & 9.32 & 15.20 & 37.64 & 1.52 & 11.78 \\
Number of effective capsules per plant & 13.52 & 28.39 & 22.67 & 0.27 & 13.26 \\
Diameter of main capsule (mm) & 5.67 & 7.08 & 64.16 & 3.91 & 9.35 \\
Seed yield per plant (g) & 18.58 & 21.15 & 77.18 & 1.72 & 33.63 \\
Husk yield per plant (g) & 19.56 & 20.67 & 89.53 & 1.93 & 38.12 \\
Latex yield per plant (g) & 14.33 & 19.11 & 56.21 & 0.02 & 22.13 \\
Harvest index for seed yield (\%) & 7.07 & 9.25 & 58.38 & 5.52 & 11.12 \\
Harvest index for latex yield (\%) & 16.66 & 21.08 & 68.75 & 0.14 & 20.07 \\
Days to maturity & 1.31 & 2.76 & 22.59 & 1.56 & 1.28 \\
\hline
\end{tabular}


Table.2 Direct (diagonal) and indirect effects of different characters towards seed yield per plant in opium poppy

\begin{tabular}{|c|c|c|c|c|c|c|c|c|c|c|c|c|}
\hline Character & $\begin{array}{l}\text { Days to } 50 \% \\
\text { flowering }\end{array}$ & $\begin{array}{l}\text { Peduncle } \\
\text { length }(\mathrm{cm})\end{array}$ & $\begin{array}{l}\text { Plant } \\
\text { Height } \\
(\mathrm{cm})\end{array}$ & $\begin{array}{l}\text { Number of } \\
\text { effective } \\
\text { capsule per } \\
\text { plant }\end{array}$ & $\begin{array}{l}\text { Diameter of } \\
\text { main } \\
\text { capsule } \\
(\mathrm{mm})\end{array}$ & $\begin{array}{l}\text { Number of } \\
\text { leaves per } \\
\text { plant }\end{array}$ & $\begin{array}{l}\text { Latex yield } \\
\text { per plant } \\
(\mathrm{mm})\end{array}$ & $\begin{array}{l}\text { Husk } \\
\text { yield per } \\
\text { plant (g) }\end{array}$ & $\begin{array}{l}\text { Harvest } \\
\text { index for } \\
\text { seed yield }\end{array}$ & $\begin{array}{l}\text { Harvest } \\
\text { index for } \\
\text { seed yield }\end{array}$ & $\begin{array}{l}\text { Days to } \\
\text { maturity }\end{array}$ & $\begin{array}{l}\text { Genotypic } \\
\text { correlation } \\
\text { with seed } \\
\text { yield per } \\
\text { plant }\end{array}$ \\
\hline Days to $50 \%$ flowering & -0.032 & -0.055 & -0.001 & -0.016 & 0.028 & 0.004 & 0.053 & 0.318 & 0.015 & -0.003 & 0.014 & $0.324 * *$ \\
\hline Peduncle length $(\mathrm{cm})$ & 0.016 & 0.110 & 0.004 & -0.013 & -0.006 & -0.003 & -0.010 & 0.014 & 0.273 & 0.005 & -0.008 & $0.381 * *$ \\
\hline Plant Height $(\mathrm{cm})$ & 0.006 & 0.068 & 0.006 & -0.017 & -0.009 & 0.003 & -0.006 & 0.165 & 0.058 & 0.004 & -0.005 & $0.271 * *$ \\
\hline Number of effective capsule per plant & -0.015 & 0.041 & 0.003 & -0.035 & -0.012 & 0.006 & 0.037 & 0.425 & -0.148 & -0.001 & -0.007 & $0.294 * *$ \\
\hline Diameter of main capsule (mm) & -0.022 & -0.018 & -0.001 & 0.011 & 0.039 & 0.004 & 0.053 & 0.287 & 0.207 & -0.003 & 0.007 & $0.563 * *$ \\
\hline Number of leaves per plant & -0.005 & -0.016 & 0.001 & -0.008 & 0.006 & 0.024 & 0.001 & -0.237 & 0.249 & -0.001 & -0.002 & 0.110 \\
\hline Latex yield per plant & -0.025 & -0.016 & -0.001 & -0.019 & 0.031 & 0.000 & 0.067 & 0.620 & -0.081 & -0.005 & 0.003 & $0.574 * *$ \\
\hline Husk yield per plant (g) & -0.010 & 0.002 & 0.001 & -0.014 & 0.011 & -0.006 & 0.041 & 1.021 & -0.283 & 0.007 & 0.002 & $0.773 * *$ \\
\hline Harvest index for seed yield & -0.001 & 0.050 & 0.001 & 0.009 & 0.013 & 0.010 & -0.009 & -0.479 & 0.602 & -0.002 & -0.004 & 0.190 \\
\hline Harvest index for latex yield & -0.008 & -0.048 & -0.002 & -0.003 & 0.010 & 0.001 & 0.027 & -0.607 & 0.077 & 0.027 & -0.001 & -0.565 \\
\hline Days to maturity & -0.033 & -0.067 & -0.002 & 0.016 & 0.018 & -0.004 & 0.014 & 0.170 & -0.154 & 0.001 & 0.014 & 0.027 \\
\hline
\end{tabular}

\section{Residual effect $=0.0058$}

Table.3 Direct (diagonal) and indirect effects of different characters towards latex yield per plant in opium poppy

\begin{tabular}{|c|c|c|c|c|c|c|c|c|c|c|c|c|}
\hline Character & $\begin{array}{l}\text { Days to } \\
50 \% \\
\text { flowering }\end{array}$ & $\begin{array}{l}\text { Peduncle } \\
\text { length }(\mathrm{cm})\end{array}$ & $\begin{array}{l}\text { Plant } \\
\text { Height }(\mathrm{cm})\end{array}$ & $\begin{array}{l}\text { No of } \\
\text { effective } \\
\text { capsule per } \\
\text { plant }\end{array}$ & $\begin{array}{l}\text { Diameter of } \\
\text { main capsule }\end{array}$ & $\begin{array}{l}\text { Number of } \\
\text { leaves per } \\
\text { plant }\end{array}$ & $\begin{array}{l}\text { Seed yield } \\
\text { per plant }\end{array}$ & $\begin{array}{l}\text { Husk yield } \\
\text { per plant }\end{array}$ & $\begin{array}{l}\text { Harvest index } \\
\text { for seed yield }\end{array}$ & $\begin{array}{l}\text { Harvest index } \\
\text { for latex yield }\end{array}$ & $\begin{array}{l}\text { Days of } \\
\text { maturity }\end{array}$ & $\begin{array}{l}\text { Genotypic } \\
\text { correlation with } \\
\text { latex yield per } \\
\text { plant }\end{array}$ \\
\hline Days to $50 \%$ flowering & 0.002 & -0.479 & 0.031 & 0.128 & 0.876 & 0.029 & -1.547 & 1.658 & 0.057 & 0.135 & 0.100 & $0.790 * *$ \\
\hline Peduncle length $(\mathrm{cm})$ & -0.001 & 0.955 & -0.105 & 0.104 & -0.197 & -0.026 & -1.818 & 0.071 & 1.055 & -0.244 & 0.059 & -0.148 \\
\hline Plant Height $(\mathrm{cm})$ & -0.0004 & 0.587 & -0.172 & 0.136 & -0.300 & 0.0245 & -1.296 & 0.861 & 0.222 & -0.190 & 0.037 & 0.090 \\
\hline $\begin{array}{l}\text { Number of effective } \\
\text { capsule per plant }\end{array}$ & 0.001 & 0.354 & -0.083 & 0.281 & -0.383 & 0.044 & -1.404 & 2.216 & -0.573 & 0.055 & 0.046 & $0.555^{* *}$ \\
\hline $\begin{array}{l}\text { Diameter of main capsule } \\
(\mathrm{mm})\end{array}$ & 0.001 & -0.151 & 0.041 & -0.086 & 1.244 & 0.030 & -2.689 & 1.497 & 0.801 & 0.149 & -0.406 & $0.792 * *$ \\
\hline Number of leaves per plant & 0.0003 & -0.137 & -0.023 & 0.067 & 0.204 & 0.182 & -.0533 & -1.237 & 0.960 & 0.029 & 0.015 & 0.009 \\
\hline Seed yield per plant & 0.0007 & 0.363 & -0.046 & 0.082 & 0.701 & 0.002 & -4.775 & 4.121 & 0.441 & -0.319 & 0.002 & $0.574 * *$ \\
\hline Husk yield per plant (g) & 0.0007 & 0.012 & -0.027 & 0.116 & 0.349 & -0.0424 & -3.690 & 5.332 & -1.091 & -0.336 & -0.016 & $0.607 * *$ \\
\hline $\begin{array}{l}\text { Harvest index for seed } \\
\text { yield }\end{array}$ & 0.00006 & 0.433 & -0.0164 & -0.069 & 0.428 & 0.075 & -0.907 & -2.502 & 2.325 & 0.0722 & 0.025 & -0.135 \\
\hline $\begin{array}{l}\text { Harvest index for latex } \\
\text { yield }\end{array}$ & 0.0005 & -0.412 & 0.057 & 0.0276 & 0.328 & 0.009 & 2.697 & -3.169 & 0.296 & 0.566 & 0.005 & $0.407 * *$ \\
\hline Days of maturity & 0.002 & -0.580 & 0.066 & -0.131 & 0.583 & -0.027 & 0.126 & 0.886 & -0.593 & -0.031 & -0.098 & 0.202 \\
\hline
\end{tabular}

Residual effect $=0.4125$ 
Days to $50 \%$ flowering $\mathrm{v} / \mathrm{s}$ seed yield per plant: A perusal of the (Table 2) indicated that the significant positive correlation of days to $50 \%$ flowering with seed yield per plant $\left(0.324^{* *}\right)$ was mainly due to its high positive indirect effect via husk yield per plant (0.318), latex yield per plant (0.053) and diameter of main capsule (0.028) whereas all other trait exerted maximum direct effect on seed yield per plant with high negative estimates.

Plant height v/s seed yield per plant: A perusal of the (Table 2) indicated that the significant positive correlation of plant height with seed yield per plant (0. 0.271**) was mainly due to its high positive indirect effect via peduncle length (0.068), number of leaves per plant (0.003), plant height(0.006) and husk yield per plant(0.165) whereas latex yield per plant $(-0.006)$, days to maturity ($0.005)$ and diameter of main capsule (-0.009)) exerted maximum direct effect on seed yield per plant with high negative estimates.

Residual effect: The component of residual effects of path analysis was (0.0058) the low residual effect indicated that characters for path analysis were adequate and appropriate.

It is concluded from above results that seed yield per plant can be improved practicing selection for husk yield per plant, latex yield per plant, peduncle length and plant height as they contributed directly to the seed yield as revealed from path analysis.

These findings are in consonance to the results obtained by Shukla et al., (2003), Ozturk and Gunlu (2008) have also reported high positive direct effect of plant height and capsule size on seed yield per plant. Mirjana et al., (2012) and Solanki et al., (2014) also reported the high positive direct effect of husk yield per plant and latex yield per plant over seed yield per plant.
The direct and indirect effect of eight dependent characters on latex yield per plant as independent character was obtained by path coefficient analysis at genotypic level.

Days to $50 \%$ flowering v/s latex yield per plant: A perusal of the (Table 3) indicated that the significant positive correlation of days to $50 \%$ flowering with latex yield per plant $(0.790 * *)$ was mainly due to its indirect positive effect through husk yield per plant (1.658), diameter of main capsules (0.876),number of effective capsule per plant (0.128), days to $50 \%$ flowering (0.002), plant height (0.031) and number of leaves per plant (0.029).

The direct contribution of peduncle length (0.476) and seed yield per plant (-0.1547) toward latex yield per plant is negative.

Number of effective capsule per plant v/s latex yield per plant: A perusal of the (Table 3 ) indicated that the significant positive correlation of number of effective capsule per plant with latex yield per plant $\left(0.555^{* *}\right)$ was mainly due to its indirect positive effect through days to $50 \%$ flowering (0.281), plant height (0.136), husk yield per plant (0.116), peduncle length (0.104) and seed yield per plant (0.082).The direct contribution of number of effective capsule per plant towards diameter of main capsule negative (-0.086).

Seed yield per plant v/s latex yield per plant: A perusal of the table 3 indicated that the significant positive correlation of seed yield per plant with latex yield per plant $(0.574 * *)$ was mainly due to its indirect positive effect through husk yield per plant (4.121), diameter of main capsules negative (0.701), number of effective capsule per plant $(0.082$, days to $50 \%$ flowering (0.002) days to maturity and number of leaves per plant (0.002). The direct contribution of number of effective capsule per plant peduncle length (-0.476), plant 
height $(-1.574)$ and harvest index for latex yield per plant (-0.319)

Diameter of main capsule per plant v/s latex yield per plant: A perusal of the table 3 indicated that the significant positive correlation of diameter of main capsule with latex yield per plan $(0.792 * *)$ was mainly due to its indirect positive effect through days to $50 \%$ flowering (1.244), seed yield per plant (0.700), husk yield per plant (0.349) and number of leave per plant (0.204). The direct contribution of peduncle length $(-0.383)$ and plant height $(-0.300)$ towards latex yield per plant is negative.

Husk yield per plant v/s latex yield per plant: A perusal of the (Table 3) indicated that the significant positive correlation of husk yield per plant with latex yield per plant $\left(0.607^{* *}\right)$ was mainly due to its indirect positive effect through husk yield per plant (4.121), days to $50 \%$ flowering (5.332), number of effective capsule per plant (2.216) diameter of main capsule (1.497) and plant height (0.861) days to maturity (0.886)). The direct contribution of husk yield per plant toward number of leave per plant negative $(-1.237)$

Residual effect: The component of residual effects of path analysis was 0.412 this moderately high residual effect indicated that characters for path analysis were not adequate and appropriate in this study.

It is concluded from above results that latex yield per plant can be improved practicing selection for days to 50 percent flowering as indicated by path analysis. These findings are in consonance to the results obtained by Shukla et al., (2003) and Dubey (2010) have also reported high positive direct effect of plant height, capsule size, and diameter of main capsule on seed yield per plant. Singh and Singh (2008) also reported the high positive direct effect of husk yield per plant and seed yield per plant over latex yield per plant.

\section{References}

Dubey, R. B. 2012. Correlation and path analysis in opium poppy (Papaver somniferum L.). Journal of Medicinal and Aromatic Plant Sciences. 32: 212216.

Jain, D. K., Jain, S. K., Bordia, P. C., Joshi, A. 2005. Study of genetic variability and correlation in germplasm of opium poppy (Papaver somniferum L.). Research on Crops, 6: 112-115.

Khatik, C.L., Sharma, S.P., Dodiya, N.S., Maloo, S.R., Joshi, A., Jain, H.K. and Padiwal, N.K.,2017. Estimate heterosis for latex yield and its related traits in opium poppy (Papaver somniferum L.). Electronic Journal of Plant Breeding, 8(1):288-293.

Mirjana, J., Sonja, I., Gjoshe, S., Jelena, A., Ljupcho, J. and Dane, B. 2012. Interrelationship between seed and capsule yield and yield contributing characters in opium poppy (Papaver somniferum L.). Agrarni Nauki. 4: 1317

Ozturk, O. and Gunlu, H. 2008. Determining relationships amongst morphine, capsule and oil yield using path coefficient analysis in opium poppy (Papaver somniferum L.). Asian Journal of Chemistry. 20: 2979-2988.

Shukla, S., Yadav, H. K. and Singh, S. P. 2003. Path coefficient analysis for seed yield in opium poppy (Papaver somniferum L.). Proceedings of the National Academy of Sciences India. Section B, Biological Sciences.73: 8388

Singh, S.K. and Singh, O.P. 2008. Character association among some morphological traits and path coefficient analysis in opium poppy. Advances in Plant 
Sciences. 21: 147-150

Singh, O. P., Singh, T. P., Yadav, A. L., Yadav, P. N., 2000. Genetic variability, genotypic and phenotypic correlation in germplasm of opium poppy (Papaver somniferum L.). Advances in Plant
Sciences. 13: 69-73.

Solanki, G., Dodiya, N.S. and Khatik, C.L., 2014. Variability and Path analysis in Opium poppy (Papaver somniferum L.). Research Journal of Agricultural Sciences, 5(6): 1084-1088.

\section{How to cite this article:}

Santra Haritwal, N.S. Dodiya and Khatik, C.L. 2017. Genetic variability and Path Analysis in Opium Poppy (Papaver somniferum L.). Int.J.Curr.Microbiol.App.Sci. 6(8): 1550-1557. doi: https://doi.org/10.20546/ijcmas.2017.608.186 